\title{
SOLVABILITY OF A NON-LOCAL PROBLEM WITH INTEGRAL GLUING CONDITION FOR MIXED TYPE EQUATION WITH ERDELYI-KOBER OPERATORS
}

\author{
Obidjon Kh. AbDullaev
}

Abstract. In this paper the existence and the uniqueness of solution of non-local problem with integral gluing condition for mixed type equation are investigated. Considering loaded parabolichyperbolic equation involve the Caputo fractional derivative and Erdelyi-Kober integrals. The uniqueness of solution is proved by the method of integral energy and the existence is proved by the method of integral equations.

Mathematics subject classification (2010): 35M10, 35R11, 35C15.

Keywords and phrases: Loaded degenerating equation, parabolic-hyperbolic type, integral operators, Caputo fractional derivative, existence and uniqueness of solution, integral equations.

\section{REFERENCES}

[1] A. A. Kilbas, H. M. SRivastava, J. J. Trujillo, Theory and Applications of Fractional Differential Equations, in: North-Holland Mathematics Studies, vol. 204, Elsevier Science B. V., Amsterdam, (2006).

[2] K. S. Miller, B. Ross, An Introduction to the Fractional Calculus and Differential Equations, John Wiley, New York, (1993).

[3] I. Podlubny, Fractional Differential Equations, Academic Press, New York, (1999).

[4] S. G. Samko, A. A. Kilbas, O. I. Marichev, Fractional Integral and Derivatives, Theory and Applications, Gordon and Breach, Longhorne, PA, (1993).

[5] R. I. BAGLEY, A theoretical basis for the application of fractional calculus to viscoelasticity, Journal of Rheology, vol. 27, no. 3, (1983), pp. 201-210.

[6] R. Magin, Fractional calculus in bioengineering, Crit. Rev. Biom. Eng., vol. 32, no. 1, (2004), pp. $1-104$.

[7] M. Ortigueira, Special issue on fractional signal processing and applications, Signal Processing, vol. 83, no. 11, (2003), pp. 2285-2480.

[8] K. B. Oldham, Fractional differential equations in electrochemistry, Advances in Engineering Software, doi: 10.1016/j.advengsoft.2008, 12012, (2009).

[9] R. MetZler, K. Joseph, Boundary value problems for fractional diffusion equations, Physics A. 278 (2000), pp. 107-125.

[10] A. Belarbi, M. Benchohra, A. OUAHAB, Uniqueness results for fractional functional differential equations with infinite delay in Frechet spaces, Appl. Anal., vol. 85, no. 12, (2006), pp. 1459-1470.

[11] M. Benchohra, J. Henderson, S. K. Ntouyas, A. OuAhab, Existence results for fractional order functional differential equations with infinite delay, J. Math. Anal. Appl., vol. 338, no. 2, (2008), $1340-1350$.

[12] K. B. SAdARAngani And O. Kh. Abdullaev, About a problem for loaded parabolic-hyperbolic type equation with fractional derivatives, Hindawi Publishing Corporation International Journal of Differential Equations, vol. 2016, Article ID 9815796, http://dx.doi.org/10.1155/ $2016 / 9815796$.

[13] A. A. Kilbas, O. A. Repin, it An analog of the Tricomi problem for a mixed type equation with a partial fractional derivative, Fractional Calculus and Applied Analysis, (2010) vol. 13, no. 1, pp. 69-84. 
[14] A. M. NAKhushev, The loaded equations and their applications, M. Nauka, 2012, p. 232.

[15] B. IsLomov, U. BALTAEVA, Boudanry-value problems for a third-order loaded parabolic-hyperbolic type equation with variable coefficients, Electronic Journal of Differential Equations, vol. 2016 (2016), no. 221, pp. 1-10.

[16] O. Kн. Abdullaev, Non-local Problem for the Loaded Integral-differential Equation in Doubleconnected Domain, JPDE, 2016, vol. 29, no. 1, pp. 1-12.

[17] O. KH. Abdullaev, A non-local problem for a mixed-type equation with a loaded integraldifferential operator, Uz. math. Journal. 2016, no. 1, p. 3-10.

[18] A. V. PSKHU, Uravneniye v chasnykh proizvodnykh drobnogo poryadka, (Russian) [Partial differential equation of fractional order], Nauka, Moscow, (2000), p. 200.

[19] M. M. SMIRnov, Mixed type equations, M. Nauka, (2000).

[20] A. V. PSKHU, Solution of boundary value problems fractional diffusion equation by the Green function method, Differential equation, 39 (10) (2003), pp. 1509-1513.

[21] I. N. SNEDdon, The use in mathematical analysis of Erdelyi-Kober operators and some of their applications, in: Fractional Calculus and Its Applications, Prof. internat. Conf. Held in New Haven, Lecture Notes in Math. 457, Springer, New York (1975), pp. 37-79. 